\title{
The Simultaneous Effect of Corporate Ownership on Dividends and Capital Structure: Malaysian Evidence
}

\author{
Mousa Sharaf Adin Hezam Saleh ${ }^{1}$, Yusnidah Ibrahim $^{2}$ \& Hanita Kadir Shahar ${ }^{2}$ \\ ${ }^{1}$ Faculty of Administrative Science, Ibb University, Yemen \\ 2 School of Economics, Finance \& Banking, University Utara Malaysia, Malaysia \\ Correspondence: Mousa Sharaf Adin Hezam Saleh, Department of Finance and Banking, Ibb University, Yemen.
}

Received: July 6, 2020

doi:10.5430/ijfr.v11n6p46
Accepted: September 1, 2020

Online Published: November 30, 2020

URL: https://doi.org/10.5430/ijfr.v11n6p46

\begin{abstract}
Most of the researchers analyzed the impact of ownership structure on dividends and capital structure decisions separately. Drawing upon preceding empirical studies, the interdependence between dividends and capital structure raises the potential of the endogeneity bias when interdependent factors are segmented. Therefore, this study examined the effect of corporate ownership structure on capital structure and dividend policy simultaneously. This study utilized 407 Malaysian-listed firms over the period from 2012 to 2016 and adopted simultaneous modelling using 2SLS and 3SLS regression techniques. The results changed markedly in sign, magnitude and significance when moving from OLS estimator to 2SLS and 3SLS estimators. The findings show that both dividend and capital structure policies have positive interdependence. The substantial, family, government and foreign ownership affect dividends positively and capital structure negatively. The study provides various theoretical and practical implications to improve corporate governance and corporate financial policies. This study contributes to the growing literature on corporate finance and corporate ownership. Particularly, it provides simultaneous investigation on the effect of family, government and foreign ownership on dividends and capital structure for Malaysian firms.
\end{abstract}

Keywords: dividends, capital structure, ownership structure, simultaneous equations

\section{Introduction}

The interaction between ownership structure, dividends and capital structure theoretically referred to the agency theory. As part of agency-based analysis, the separation of ownership, control, and management in corporations raises the issue of agency costs. In firms with widely dispersed ownership, the managers will not always act in the best interest of the shareholders and to limit the divergences from shareholders' interests, appropriate monitoring shall be established to limit the aberrant activities (Jensen \& Meckling, 1976). Therefore, the types and compositions of firms' ownership structure are important factors that influence the level of agency problem and constitute the governance system. Both capital structure and dividend policy are proven as governance mechanisms to alleviate the agency problem in firms. To avoid managers' unfavorable actions, shareholders strive to distribute as much as possible of free cash flow as dividends and place the managers under capital market monitor (Easterbrook, 1984; Rozeff, 1982).

The literature has provided evidence on the interdependence of capital structure and dividend and should be addressed simultaneously (Jensen, Solberg, \& Zorn, 1992; Kim, Rhim, \& Friesner, 2007; Lee et al., 2016). Myers (1984) argued that dividend payments influence the firms' reliance on internal funds. The sticky dividends behaviour inducing firms with high dividends for new external finance. However, firms that have higher leverage obligations are reluctant to raise dividend payments. Rozeff (1982), Easterbrook (1984), and Jensen (1986) argued that dividends and capital structure are effective devices used to mitigate agency costs. While dividends reduce the available cash that managers may use at the expense of owners interests, debt financing induces capital market monitoring. Kim et $a l$, (2007) discussed that considering the monitoring role of dividends and capital structure, it is reasonable to expect that firms attempt to use the optimal combination of policies that minimizes agency costs. Therefore, capital structure is not determined independently, but rather simultaneously with a firm's dividend policy.

Rozeff (1982) and Easterbrook (1984) pointed out that the use of dividends and capital structure as a governance device is less needed for firms with concentrated ownership structure. The presence of ownership concentration 
reduces the agency conflicts and creates an effective mechanism on the alignment of interests between shareholders and managers. Nevertheless, the impact of ownership structure on capital structure and dividend policy is unclear. Researchers suggest that the roots of agency cost are not only due to managers-owners conflicts. Ownership concentration may induce large shareholders to expropriate wealth from minority, which raises the conflict between minority and majority shareholders (Faccio et al., 2001; La Porta et al., 2000b; Shleifer \& Vishny, 1986). Therefore, the need for dividend and capital structure monitoring role is applied for firms with high concentration ownership, and the level of firms' agency problem is determined through the interaction between ownership structure, capital structure and dividend variables (Djebali, 2015; Kim et al., 2007).

Furthermore, different identities of block-shareholders (family, government, and foreign ownership) may show different preferences toward capital structure and dividend policy. Even though the literature review provides a number of studies that examined the effect of types and identities of ownership on dividend and capital structure decisions, the reported findings are inconsistent and separately addressed (Al-Najjar \& Kilincarslan, 2016; Anderson \& Reeb, 2003; Croci, Doukas, \& Gonenc, 2011; Djebali, 2015; Le \& Tannous, 2016; Pindado, Requejo, \& Torre, 2012). Since these two choices have to be simultaneously addressed, statistically, previous studies are more likely to produce biased results because of the endogeneity problem when interdependent factors are segmented (Wooldridge, 2010). The present study is based on an alternative approach to that employed in previous literature. Therefore, this study contributes to the literature by examine the effect of ownership concentration on dividends and capital structure simultaneously. Furthermore, it examines whether the identities of controlling shareholders show a different effect on dividends and capital structure using effective approach of method.

Malaysia provides an ideal setting to explore this issue because of that the firms' ownership structure has been reported to be highly concentrated and dominated by various identities of block-shareholders (Ghasemi, AB Razak and Muhamad, 2018). Saleh, Ibrahim, and Shahar (2018a) reported that the substantial shareholders possess, on the average, $56.9 \%$ of firm's shareholdings. The high concentration ownership and close alignment between managers and large shareholders increase the threat of expropriation from minority shareholders in Malaysia. Haniffa and Hudaib (2006) assert that in Malaysia, minority shareholders resort to sell their shares as a disciplinary action to express their dissatisfaction with the firm's policies. Furthermore, In Malaysia, the dividends rules are regulated by the Companies Act 1965 and its amendment in 2017, the only limitations on determining when and how much to pay dividends is that related to creditors right and firms' solvency. Besides that, there has been a tremendous increase in the reliance on debt financing in the Malaysian market (Tam \& Tan, 2007). With such circumstances, managers in Malaysia need to better understand the preferences of shareholders and act for the appropriate approach to satisfy majority and minority shareholders. Thus, this study attempts to provide clear insight to managers regarding the preferences of shareholders toward capital structure and dividend policy by examining the effect of different types of ownership structure on the capital structure and dividend policy in a simultaneous framework.

\section{Literature Review and Hypothesis Development}

\subsection{Interrelationship Among Dividends and Capital Structure}

The extant literature provides conflicting interpretations regarding the relationship between dividend policy and capital structure. Researchers argued that the combination of pecking order analysis with Lintner dividend model suggests a positive relationship between dividend and capital structure (Baskin, 1989). Given the sticky dividend assumption suggested by the Lintner model, firms with high dividends are expected to pay greater dividends in future. Myers (1984) argued that the information asymmetry between managers and outside investors put extra costs on external finance, thus firms prefer internal funds and the internal deficit is financed first by the less risky debt. Accordingly, pecking order theory implies that firms with higher dividends will have less internal financing and therefore higher leverage. Mookerjee (1992) tested the Lintner model including external finance as the independent variable. The results indicate a positive relationship between dividends and external finance by borrowing.

Alternatively, based on agency analysis, it has been argued that both dividends and capital structure could be substitutes or complements in mitigating the firms' agency costs. Dividends reduce the excess cash under the managers' discretion and increase the firm's dependence on the financial market and thus induce market monitoring on management (Easterbrook, 1984; Jensen, 1986). Belden et al. (2005) suggested that capital structure can be used as an alternative of dividends to reduce agency costs. They found that firms use debt in addition to dividends to control agency problems. Kim et al. (2007) found a positive relationship between dividends and capital structure. They suggested that debt and dividends are complementary policies to reduce agency costs. Ghasemi et al. (2018) suggested that when ownership structure leads to align the interests of managers and owners, dividends and leverage are substitutes and when the firm's agency status call for more monitoring efforts, debt and dividends are 
complements. Dutta (1999), Aggarwal and Kyaw (2010), and Khan and Adom (2015) found positive relationship between dividends and capital structure.

In contrast, there are considerable empirical studies that showed negative results. Researchers argued that high leverage ratio increased the corporate risk and in consequence, raise the cost of external financing which make firms depend more on internal financing (Jabbouri, 2016; Rozeff, 1982). Rozeff (1982) argued that the firm's risk and the transaction costs increase with a high leverage ratio. Therefore, firms with high leverage ratios pay higher interest expenses and costs of capital. As a consequence, the chance for firms to pay dividends declines as the leverage ratio increases, and a negative association is expected between dividends and capital structure. Jabbouri (2016) posited that a high debt ratio increases the firm's financial risk and cost of finance, thus, firms tend to have a low dividend policy to reduce its financial risks. He found a negative relationship between dividends and financial leverage. Abdulkadir et al. (2016) also provided strong evidence for Rozeff's (1982) explanation as their results showed that dividends decrease as leverage increase. Kuwari (2009), Lee et al. (2016), and Yusof, Ismail, and Ali (2016) also found a negative relationship between dividends and capital structure. Based on the literature, the study hypothesizes that:

H1a: Dividend payout affects capital structure.

H1b: Capital Structure affects Dividends payout.

\subsection{Ownership Structure}

As part of the agency-based analysis, the ownership structure is from the most important factors that influence the level of agency problem and constitute the governance system which in turn reflects on the financial decisions. The separation of ownership, control, and management in corporations leads to high agency costs. Managers will not always act in the best interest of the shareholders and to limit the divergences from shareholders' interests, appropriate monitoring shall be established to limit the aberrant activities (Jensen \& Meckling, 1976). In firms with widely dispersed ownership, the free-rider problem is severe where the individual shareholder has not enough incentive to incur monitoring costs for the benefit of all shareholders (Short et al., 2002). Shleifer and Vishny (1986) argue that ownership concentration mitigates agency problem, large shareholders have the motive to monitor the firm's managers.

Nevertheless, the agency-based analysis, in the last decade, has been extended to give more concern to the potential conflicts among shareholders. In emerging markets, agency problems between controlling shareholders and minority shareholders are more crucial than those between managers and shareholders (Al-Jaifi, 2017; Faccio et al., 2001; Mulyani et al., 2016). Faccio et al. (2001) asserted that the expropriation of minority shareholders' wealth by the controlling shareholders is the main agency problem in East Asian firms. In countries with high ownership concentration, the protection of minority shareholders is an issue where controlling shareholders might manipulate information and use corporate assets not to enhance profitability but rather to retain control over the firm.

Drawing on the agency analysis, literature on ownership structure provides inconsistent predictions regarding its effect on dividends and capital structure. Rozeff (1982) and Easterbrook (1984) suggest that ownership concentration substitutes the monitoring role of dividends and capital structure. Active monitoring of large shareholders increases the alignment of interests between managers and shareholders and ensures better firm performance. Therefore, a negative relationship is expected between ownership concentration and dividends and capital structure. Short et al. (2002) suggests that the presence of large shareholders reduce the managers' negative actions on firm value and mitigate the need of debt as a means to monitor mangers. Furthermore, the information asymmetries associated with ownership concentration and the reluctance to minimize non-diversifiable risk result in a negative relationship with capital structure (Farooq, 2015; Rajan \& Zingales, 1995).

Alternatively, researchers consider the low dividends associated with high concentration as a signal of expropriation (Harada \& Nguyen, 2011; La Porta et al., 2000a). Shleifer and Vishny (1997) argue that large shareholders like managers could choose to reduce dividends and use cash in activities that provide private benefits for them. According to La Porta et al. (2000a), high dividends are an outcome of good governance and shareholders protection. Hence, the positive relationship between dividend and ownership concentration is a consequence of large shareholders' monitoring.

Likewise, Rossi et al. (2016) argued that the positive relationship between ownership concentration and capital structure could be simultaneously interpreted as either a complementary role to mitigate agency conflicts between managers and owner or a controlling shareholder attempts to extract benefits from the minority. Friend and Lang (1988) and Mehran (1992) suggested that external shareholders have more diversified portfolio than managers 
leading them to be less aversion toward risk associated with debt. In addition, large shareholders attempt to maintain a strong voting power over the firm by using more debt (Brailsford et al., 2002; Céspedes et al., 2010).

From the above discussion it can be hypothesized that:

H2: There is a relationship between ownership concentration and both dividend payout and capital structure.

\subsubsection{Family Ownership}

The involvement of family affiliation in businesses implements a unique feature of corporate policies. Family shareholders are characterized by having direct representation in management, longer investment horizons, and relatively undiversified portfolio. Although the direct representation of family members in the management reduces the costs of manager-owner conflicts, family firms are accused of expropriation threat. Setia-Atmaja (2010) argued that the presence of family ownership increases agency costs and thus, the need for governance mechanisms. The greater incentives to expropriate wealth from minority and probable conflicts with other block-holders such an insisting on keeping incompetent managers because he is a family member suggest that agency problem might be more severe in firms with family control. Therefore, controlling families strive to keep a good reputation for their family group through the appropriate corporate policies.

Yoshikawa and Rasheed (2010) suggested that in family-controlled firms, one of the critical agency conflicts is the conflict between inside family shareholders and other outside block-shareholders. Their results showed that dividends are positively related to family directors. Similarly, Pindado et al. (2012) examined the use of dividends as a governance tool in family-controlled firms in Eurozone countries. They found that family firms tend to pay more dividends and keep a stable dividend policy as compared to non-family firms. Saleh et al. (2018a) affirm that the severity of agency problems compels Malaysian family-controlled firms to pay higher dividends regardless of their financial needs for growth opportunities. However, Djebali (2015) reported a negative relationship between dividends and family ownership. He attributes that to families' reservations about future growth opportunities and preference to tunnel dividends to their affiliated firms, thus, keeping the business resources and benefits under their control.

Based on existing literature, there is no absolute decisive prediction regarding family shareholders' preferences toward the choice of capital structure. The concern of keeping control over the firms leads family shareholders to prefer debt finance (Pindado et al., 2015). Croci et al. (2011) found that family firms are more affected by control-motivation and prefer debt financing compared to non-family controlled firms. However, the control-incentive is not always held where the creditors' restraints on controlling shareholders via covenants (Anderson \& Reeb, 2003; McConaughy, 2009) and the poor diversified portfolio of family shareholders make family firms more sensitive to risks associated with debt financing (Faccio et al., 2011). Based on the discussion above it can be hypothesized that:

H3: There is a relationship between family ownership and dividend payout and capital structure.

\subsubsection{Government Ownership}

Government ownership in capital markets is taken as a special case due to several considerations. Firms that are controlled by the government are more concerned about the country's aggregate economy, political and social policy goals (Dewenter \& Malatesta, 2001). Based on agency analysis, government ownership is expected to reveal double agency costs. Besides the conflicts that may arise between the shareholders (majority and minority), government ownership raises the probability of conflicts between the government and the citizens as the ultimate owners (Eng \& Mak, 2003; Al-Malkawi, 2017).

Managers of government-owned firms are poorly monitored and evaluated by politicians as agents for citizens, the ultimate owners of these firms (Ben-Nasr, 2015). Ben-Nasr (2015) and Al-Najjar and Kilincarslan (2016) found a negative relationship between government ownership and dividends. They suggested that managers and politicians may strive to keep cash within the firm for achieving personal and political desires that keep them in power for a longer period.

However, other researchers argued that since the governments are expected to hold the responsibility of protecting investors, this suggests high monitoring role of government ownership to reduce the managers' misuse of authorities on firms' policies (Kuwari, 2009; Al-Malkawi, 2017). In emerging markets, the protection of investors is questionable, with high uncertainty about the firms' future and lack of experience about how to treat minority rights. Thus, the expropriation risk is high, and governments attempt, through their participation in the capital market, to show the good reputation of firms by distributing a large dividend payout (Kuwari, 2009). Several empirical studies 
reported a positive relationship between dividends and government ownership (Al-Malkawi, 2017; Kuwari, 2009; Lin et al., 2017).

On the other hand, literature has shown inconclusive results regarding the effect of government shareholding on capital structure. The government domination on the financial system and control over most banks and financial institutions allow firms controlled by the government easier access to external funds and on favorable terms (Chen $e t$ al., 2014; Li et al., 2009; Pöyry \& Maury, 2010). Such financial privileges suggest a positive relationship between government ownership and firms' financial leverage. The financial privileges of government-controlled firms have been supported empirically (Chen et al., 2014; Le \& Tannous, 2016; Li et al., 2009; Pöyry \& Maury, 2010).

On the contrary, Chen and Strange (2005) suggested that government ownership increases the entrenchment of managers who are more concerned about the risk associated with debt financing, and thus the presence of state shareholders limits the use of debt. Su (2010) found that firms controlled by the government use less debt than nongovernment -controlled firms. He suggested that debt is less likely to be an effective governance tool to discipline the managers of government-controlled firms. Hardiyanto et al. (2015) and Nhung and Okuda (2015) found a negative impact of government ownership on the firms' financial leverage. Hence it is hypothesized that:

H4: There is a relationship between government ownership and dividend payout and capital structure.

\subsubsection{Foreign Ownership}

The finance literature has highlighted the differential impact of foreign ownership on firms' policies and its performance implications (Douma et al., 2006). Foreign investors practice international standards, demand strong corporate governance and have better experience compared to local investors which is reflected in better performance of firms and in the overall growth of the economy ( Jeon et al., 2011; Mian \& Nagata, 2015). Lam et al. (2012) argued that the presence of foreign ownership pressures local firms to improve corporate governance and reduce asymmetric information about the firms. Such an environment reduces the need for dividend-induced monitoring, predicting a negative relationship between dividends and foreign ownership. The negative impact of foreign ownership on dividends also found by Yoshikawa and Rasheed (2010).

In contrast, Manos (2002) and Baba (2009) argued that, unlike domestic shareholders, foreign investors encounter a high degree of information asymmetry, and difficulty of monitoring managers overseas. Therefore, the increase in foreign ownership leads to greater dividend payouts. However, other researchers consider the positive effect of foreign ownership on dividends as a result of applying strong corporate governance. Jeon et al. (2011) argued that foreign shareholders pressure firms to pay more dividends in order to enhance shareholders monitoring and reduce the problem of overinvestment. Mian and Nagata (2015) suggested that foreign shareholders, especially institutions, consolidate the efficient use of dividends and investments policy to increase the firm value.

Foreign affiliated firms are financially stronger firms with greater investment opportunities and the equity contribution from foreign investors may lead to the use of less debt (Bandyopadhyay \& Barua, 2016). Gurunlu and Gursoy (2010) pointed out that foreign investors encounter more risks relative to local investors, these risks involve country risk, currency risk, and business risk. They found that foreign ownership is negatively related to leverage. Chen and Strange (2005) and Li et al. (2009) provided empirical support for the negative effect of foreign ownership on capital structure. Le and Tannous (2016) suggested that foreign ownership serves as a substitute for leverage-induced monitoring. The foreign investors' privileges of accessing and interpreting information help to reduce agency costs and control the overinvestment problem. Therefore, this study hypothesizes that:

H5: There is a relationship between foreign ownership and dividends payout and capital structure.

\section{Methodology and Estimating Technique}

\subsection{Sample and Data Characteristics}

The study is conducted on selected firms from the population of all listed firms on the Main Market of Bursa Malaysia for five years period from 2012 to 2016. The financial related firms are excluded as they are subject to different regulations. The study excluded firms in the ACE market because it adopts a simple listing requirement in terms of size, growth, operating history, and track record of firms to enable emerging firms to gain an advantage as being listed firm. Firms with negative earnings are excluded from the sample, as these firms refrained from paying dividends not because of rational monitoring or financing action but because they are unable to pay dividends. Thus, the sensible interpretation of firms' dividends behavior calls for excluding these firms. (Jensen et al., 1992; Mulyani et al., 2016; Setia-Atmaja, 2010). Furthermore, only firms that have complete data over the period of study were included in the sample. Finally, 407 firms (2035 observations-year firms) were included in the sample. The 
ownership structure variables are collected from the firm's annual reports available on the Bursa Malaysia website. Data for the other variables are collected from the DataStream of Thomson database.

Table 1 shows the number of firms in each sector. The sample included firms from ten sectors. The sectors of Industrial Products and Trading \& Service have the largest representation in the sample which is $27.2 \%$ and $21.8 \%$ respectively, whilst the Infrastructure Project Companies (IPC) represents the smallest percentages of sample firms that consisted of only $0.98 \%$ of the sample firms.

Table 1. Profiles of Sample firms between 2012 to 2016

\begin{tabular}{lllllll}
\hline Sector & No & $\%$ & Dividends Payers & Non-dividends payers & Dividend Payout & Leverage \\
\hline Construction & 26 & 6.38 & 21 & 5 & 0.144 & 0.373 \\
\hline Consumer Products & 69 & 16.95 & 60 & 9 & 0.338 & 0.183 \\
\hline Hotels & 1 & 0.24 & 1 & 0 & 0.413 & 0.035 \\
\hline Industrial Products & 111 & 27.27 & 91 & 20 & 0.337 & 0.216 \\
\hline Plantation & 23 & 5.65 & 23 & 0 & 0.51 & 0.161 \\
\hline IPC & 4 & 0.98 & 3 & 1 & 0.419 & 0.286 \\
\hline Properties & 58 & 14.25 & 45 & 13 & 0.154 & 0.333 \\
\hline REITS & 15 & 3.68 & 15 & 0 & 0.592 & 0.321 \\
\hline Technology & 11 & 2.70 & 11 & 0 & 0.37 & 0.088 \\
\hline Trading/Services & 89 & 21.86 & 81 & 8 & 0.376 & 0.219 \\
\hline Total & 407 & 100 & 351 & 56 & 0.332 & 0.244 \\
\hline
\end{tabular}

Table 1 also reports the number of firms that paid dividends in each sector and non-dividend payer. Overall, 351 firms paid dividends which represent $86 \%$ of the sampled firms. REITS firms are shown to have the highest dividend payout ratio at $59.2 \%$, and Construction firms had the lowest payout ratio of $14.4 \%$. The average leverage ratio varied among sectors from the highest (37.3\%) for Construction firms to the lowest (8.8\%) for Technology firms

\subsection{Estimating Technique}

It has been argued that in the OLS model, the independent variables are assumed to be exogenously determined. For consistent estimation of OLS, the independent variable should not be correlated to the unobserved value that represented in the error value of the model. If such an assumption is infringed, the regression model will be subject to the endogeneity problems and biased results are expected (Wooldridge, 2010). In statistic, the endogeneity bias appears when the dependent variable is simultaneously determined with one or more of the independent variables "endogenous variable" (Roberts \& Whited, 2013). In such circumstances, there will be an association between the error term of the model and the independent variable "endogenous variable". This association raises the endogeneity problem in the model, which leads to bias results. This association affects the estimated parameters of other exogenous variables as well unless they are totally uncorrelated to the endogenous variable (Cameron \& Trivedi, 2005). The Equations in simultaneous model can be rewritten as follow:

$$
\begin{aligned}
& Y=\beta_{0}+\partial X+\sum_{j=1}^{j} \beta_{j} x_{j}+u \\
& X=\beta_{0}+\delta Y+\sum_{k=1}^{k} \beta_{k} x_{k}+\varepsilon
\end{aligned}
$$

Where $Y$ and $X$ represent the dependent variable, which are the endogenous variable (it may be there a vector of endogenous variables), $x_{\mathrm{j}}$ and $x_{k}$ are the exogenous variables, $\partial, \delta$, and $\beta_{j}$ are the parameters that the study aims to estimate, $\varepsilon$ and $u$ are the error term.

To avoid bias results due to the endogeneity problem, researchers adopt one of the Instrumental Variable techniques (IV). The IV methods resolve the endogeneity problem by finding instruments that satisfy the assumption of consistent estimation. This instrument should be uncorrelated to the error term but sufficiently correlated to the endogenous variable (Cameron \& Trivedi, 2005). Based on the IV methods,,$X$ in Equation 2 is regressed on all 
other exogenous variables in equation 2 in order to find the fitted instruments ( $\tilde{y})$ that used in the second stage to regress Y on ( $\tilde{\mathrm{y}}$ ) and $x_{k}$ (exogenous variables) to obtain $\bar{\beta}_{j}$ (Cameron \& Trivedi, 2005). The IV techniques can be performed equation-by-equation using two-stage least squares (2SLS) or full system of equations using the three-stage least squares (3SLS). The 2SLS estimator for $\bar{\beta}_{j}$ can be written as follow:

$$
\bar{\beta}_{j 2 s l s}=\left(\tilde{y}^{\prime} x_{k}\right)^{-1} \tilde{y}^{\prime} Y
$$

Where $x_{k}$ is a matrix includes all exogenous variables. According to Wooldridge (2010), 2SLS estimator is the most efficient estimator among the class of IV estimators. The 2SLS approach uses all exogenous variable in the regressed equation as instrumentals to obtain the predicted value of the endogenous variable. However, 3SLS is more informative estimator as it takes into account the contemporaneous correlation between the error terms in the system across equations (Lee et al., 2016). Wooldridge (2010) asserted that 3SLS and 2SLS are asymptotically equivalent when each equation in the system is just identified.

\subsection{Econometric Model}

As discussed in the literature review dividends and capital structure are highly confirmed as jointly determined decisions. Jensen et al, (1992), Aggarwal and Kyaw (2010), Lee et al. (2016), and Ghasemi et al. (2018) found that dividend policy and capital structure are co-determined. They concluded that capital structure and dividend decisions should be investigated in a simultaneous estimation technique. Therefore, this study utilizes the 2SLS and 3SLS to estimate the simultaneous relationship between dividends and capital structure. Two simultaneous equations are specified, each equation identifies one endogenous variable along with the other exogenous variables.

$$
\begin{gathered}
D I V=\beta_{0}+\beta_{1} L E V+\beta_{2} C O N+\beta_{3} F A M I L Y+\beta_{4} G O V+\beta_{5} F O R E I G N+\beta_{6} T Q+\beta_{7} R O A+\beta_{8} B E T A+\beta_{9} S T D V+ \\
\beta_{10} S A L E G R T H+\beta_{11} F C F+\varepsilon \\
L E V=\delta_{0}+\delta_{1} D I V+\delta_{2} C O N+\delta_{3} F A M I L Y+\delta_{4} G O V+\delta_{5} F O R E I G N+\delta_{6} T Q+\delta_{7} R O A+\delta_{8} B E T A+\delta_{9} S T D V+ \\
\delta_{10} \text { COVERAG }+\delta_{11} T A N G+\sigma
\end{gathered}
$$

The capital structure (LEV) is measured by the market value of the leverage ratio. Rajan and Zingales (1995) argued that market value of leverage is the efficient measurement relative to the agency problem, that because it reflects the residual for the shareholders from the firm value in the case of liquidation. Dividends (DIV) are measured as the ratio of cash dividends to the operating income (Kim et al., 2007). As discussed in the previous section, dividends and capital structure seem to be simultaneously ownership variables (CON, FAMILY, GOV, and FOREIGN). Therefore, they have been added as exogenous variables for both dividends and capital structure equations.

Fallowing pervious literature, profitability (ROA), investment opportunities (TQ), and corporate risk (BETA, STDV) are key determinants of dividends and capital structure. According to pecking order theory, dividends are less attractive with lower profitability and greater investment opportunities. Similarly, when investment exceeds retained earnings, more external finance will be needed. Thus, debt increases when profitability decreases and investment opportunities increases (Fama \& French, 2002; Myers, 1984). Similarly, Fama and French (2002) argued that both trade-off and pecking order theory predict a negative effect of earnings volatility on dividends and capital structure. Firm risk add extra costs on external finance, hence firms with high risk prefer to keep lower payout ratio and lower leverage.

The simultaneous equation modeling is required instrumental variables at least as large as the number of endogenous variables for each structural equation to satisfy the assumption of model identification. Thus, two specific exogenous variables were added to each system equation as instrumental variables. In this study, sales growth (SALEGRTH) and free cash flow (FCF) were used as instrumental variables in the dividends equation (Aggarwal \& Kyaw, 2010; Jensen et al, 1992; Vo and Nguyen, 2014). Rozeff (1982) and Jensen et al, (1992) suggested that sales growth is associated with higher investment expenditures. Therefore, firms with high sales growth establish lower dividend payout to avoid costly external finance. According to agency theory, dividends are used to reduce cash under managers' discretions. Thus as free cash flow increases, firms use more dividends. Similarly, two instrumental variables were added to the capital structure equation: coverage ratio (COVERAG) and asset tangibility (TANG). According to Eriotis et al, (2007), high-interest coverage ratio indicates lower default probability due to lower leverage. The trade-off theory predicts a positive relation between leverage and tangibility. Tangible assets are easier to collateralize and they suffer a smaller loss of value when firms go into distress (Köksal \& Orman, 2015). Table 2 presents the measurements and acronym of each variable. 
Table 2. The variables' measurements

\begin{tabular}{|c|c|c|c|c|}
\hline No. & Variables & Acronym & Measurements & Study/References \\
\hline \multicolumn{5}{|c|}{ Dependent variables (endogenous) } \\
\hline 1 & Dividends & DIV & $\begin{array}{l}\text { Payout ratio: cash dividend to } \\
\text { operation income. }\end{array}$ & $\begin{array}{l}\text { Harada and Nguyen (2011), Kim } \\
\text { et al. (2007) }\end{array}$ \\
\hline 2 & Capital structure & LEV & $\begin{array}{l}\text { Ratio of total debt to (market } \\
\text { value of equity +total debt) }\end{array}$ & $\begin{array}{l}\text { Pindado et al. (2015), Short et } \\
\text { al. (2002) }\end{array}$ \\
\hline \multicolumn{5}{|c|}{ Independent variables (exogenous) } \\
\hline 1 & $\begin{array}{l}\text { Ownership } \\
\text { concentration }\end{array}$ & $\mathrm{CON}$ & $\begin{array}{l}\text { The percentage of shares held } \\
\text { by shareholders who owned } \\
5 \% \text { or more of shareholdings }\end{array}$ & $\begin{array}{l}\text { Yunos et al. (2010), Eng and } \\
\text { Mak (2003) }\end{array}$ \\
\hline 2 & $\begin{array}{l}\text { Family } \\
\text { ownership }\end{array}$ & FAMILY & $\begin{array}{l}\text { The ratio of share owned by } \\
\text { family members. }\end{array}$ & Anderson and Reeb (2003) \\
\hline 3 & $\begin{array}{l}\text { Government } \\
\text { ownership }\end{array}$ & GOV & $\begin{array}{l}\text { The ratio of shares held by } \\
\text { government. }\end{array}$ & $\begin{array}{l}\text { Kuwari (2009), Lin et al. (2010), } \\
\text { Chen et al. (2014) }\end{array}$ \\
\hline 4 & $\begin{array}{l}\text { Foreign } \\
\text { ownership }\end{array}$ & FOREIGN & $\begin{array}{l}\text { The ratio of shares owned by } \\
\text { foreign }\end{array}$ & Li et al. (2009), Baba (2009), \\
\hline 5 & $\begin{array}{l}\text { Growth } \\
\text { opportunities }\end{array}$ & TQ & $\begin{array}{l}\text { Tobin's } \mathrm{Q}=\text { (total debt }+ \\
\text { market value of equity)/ total } \\
\text { asset. }\end{array}$ & $\begin{array}{l}\text { Fama and French (2002), } \\
\text { Aggarwal and Kyaw (2010) }\end{array}$ \\
\hline 6 & Profitability & ROA & Net income to total assets. & Fama and French (2002) \\
\hline \multirow[b]{2}{*}{7} & \multirow[b]{2}{*}{ Corporate risk } & STDEV & $\begin{array}{l}\text { Standard deviation of the first } \\
\text { difference in operating income } \\
\text { divided by total asset. }\end{array}$ & $\begin{array}{l}\text { Jensen et al. (1992), Aggarwal } \\
\text { and Kyaw (2010) }\end{array}$ \\
\hline & & BETA & $\begin{array}{l}\text { Beta }=\text { the covariance of stock } \\
\text { return with market return } \\
\text { divided by variance of market } \\
\text { return. }\end{array}$ & $\begin{array}{l}\text { Rozeff (1982), Aggarwal and } \\
\text { Kyaw (2010) }\end{array}$ \\
\hline 8 & Sales growth & SALEGRTH & $\begin{array}{l}\text { Ratio of change in sale for } \\
\text { current year related to last } \\
\text { year. }\end{array}$ & $\begin{array}{l}\text { Jensen et al. (1992) Vo and } \\
\text { Nguyen (2014) }\end{array}$ \\
\hline 9 & Free cash flow & FCF & Net income + depreciations & $\begin{array}{l}\text { Aggarwal and Kyaw (2010), Le } \\
\text { and Tannous (2016), Yusof et } \\
\text { al. (2016) }\end{array}$ \\
\hline 10 & Coverage ratio & COVERAG & $\begin{array}{l}\text { The ratio of operating income } \\
\text { to interests' expenses. }\end{array}$ & Eriotis et al, (2007) \\
\hline 11 & $\begin{array}{l}\text { Tangibility of } \\
\text { Assets }\end{array}$ & TANG & Fixed assets to total assets. & Köksal and Orman (2015) \\
\hline
\end{tabular}

\section{Empirical Results and Analysis}

\subsection{Descriptive Statistics}

Table 3 the descriptive statistics of the variables undertaking by the study. The overall mean dividend payout for the whole sample over the period of study is 0.33 , which is a similar percentage that was reported by Benjamin et al. (2016) for a sample of Malaysian firms. The mean value of the leverage ratio is 0.24 . Based on studies of Malaysian firms, the mean value of leverage ratio ranged between $31 \%$ as reported by Lean et al. (2011) and $15.28 \%$ as reported by Suhaila et al. (2008). The difference in values is perhaps due to the difference in sample period and sample selection criteria. Ownership concentration $(\mathrm{CON})$ as measured by the percentage of shareholdings owned by 
substantial shareholders (5\% or more equity shareholding) has a mean value of 0.56 and ranges from $11.8 \%$ to $89 \%$. These statistics indicate a high level of concentration ownership in Malaysia where all the sample firms have substantial shareholders. These percentages are consistent with Yunos et al. (2010) who found that 96.76\% of Malaysian firms in the sample have concentrated ownership with substantial shareholdings higher than $20 \%$.

Table 3. Descriptive statistics

\begin{tabular}{llllll}
\hline Variable & Obs & Mean & Std. Dev. & Min & Max \\
\hline DIV & 2,035 & 0.331675 & 0.540244 & 0 & 14.84799 \\
\hline LEV & 2,035 & 0.244314 & 0.224936 & 0 & 0.976079 \\
\hline CON & 2,035 & 0.568177 & 0.148647 & 0.1181 & 0.8934 \\
\hline FAMILY & 2,035 & 0.245471 & 0.255919 & 0 & 0.8546 \\
\hline GOV & 2,035 & 0.088096 & 0.174509 & 0 & 0.9042 \\
\hline FOREIGN & 2,035 & 0.118542 & 0.185723 & 0 & 0.8944 \\
\hline TQ & 2,035 & 1.107603 & 1.260718 & 0.110693 & 15.49756 \\
\hline ROA & 2,035 & 0.075663 & 0.068355 & 0 & 0.7532 \\
\hline BETA & 2,035 & 0.629689 & 0.563596 & -0.60445 & 2.811773 \\
\hline STDV & 2,035 & 0.036035 & 0.035755 & 0.0019 & 0.526529 \\
\hline SALEGRTH & 2,035 & 0.141281 & 0.95015 & -0.967 & 30.76483 \\
\hline FCF & 2,035 & 0.054734 & 0.055393 & -1.23947 & 0.340541 \\
\hline COVERAG & 2,035 & 0.177767 & 1.025083 & -7.01957 & 41.83333 \\
\hline TANG & 2,035 & 0.345807 & 0.236542 & 0 & 0.996648 \\
\hline
\end{tabular}

Table 4 shows that the correlations among variables are relatively low. The highest value is $38.5 \%$ for the correlation between profitability (ROA) and the leverage ratio (LEV). Therefore, it can be concluded that both models are free from multicollinearity problem.

Table 4. Correlation matrix

\begin{tabular}{llllllll}
\hline Variables & DIV & LEV & CON & FAMILY & GOV & FOREIGN & TQ \\
\hline DIV & 1 & & & & & & \\
\hline LEV & 0.2216 & 1 & & & & & \\
\hline CON & 0.0886 & -0.137 & 1 & & & & \\
\hline FAMILY & -0.0522 & -0.0317 & 0.0781 & 1 & & & \\
\hline GOV & 0.1508 & -0.0515 & 0.2236 & -0.3039 & 1 & & \\
\hline FOREIGN & 0.0904 & -0.2266 & 0.1471 & -0.0891 & -0.0229 & 1 & \\
\hline TQ & 0.1877 & -0.3224 & 0.1136 & -0.1533 & 0.1463 & 0.2387 & 1 \\
\hline ROA & 0.1109 & -0.3859 & 0.051 & -0.0235 & 0.0336 & 0.1732 & 0.7372 \\
\hline BETA & -0.1011 & 0.0225 & -0.1581 & -0.0471 & 0.005 & -0.0699 & 0.0127 \\
\hline STDV & 0.0102 & -0.1884 & 0.0528 & 0.0008 & -0.0297 & 0.1139 & 0.2045 \\
\hline SALEGRTH & -0.058 & 0.0399 & 0.0157 & 0.0195 & -0.0156 & -0.0229 & -0.013 \\
\hline FCF & 0.2932 & -0.1851 & -0.0272 & 0.057 & -0.0423 & 0.025 & 0.1096 \\
\hline COVERAG & 0.284 & 0.1847 & -0.0211 & 0.0056 & 0.0086 & -0.0474 & -0.0498 \\
\hline & & & & & & & \\
\hline
\end{tabular}




\begin{tabular}{|c|c|c|c|c|c|c|c|}
\hline TANG & 0.0503 & 0.0363 & 0.0796 & -0.0414 & 0.1513 & 0.009 & 0.0028 \\
\hline & ROA & BETA & STDV & SALEGRTH & FCF & COVERAG & TANG \\
\hline ROA & 1 & & & & & & \\
\hline BETA & 0.1088 & 1 & & & & & \\
\hline STDV & 0.237 & 0.0468 & 1 & & & & \\
\hline SALEGRTH & 0.0294 & 0.0357 & 0.0225 & 1 & & & \\
\hline FCF & 0.3756 & 0.1543 & -0.0187 & 0.0386 & 1 & & \\
\hline COVERAG & -0.0924 & -0.0222 & -0.0368 & -0.0056 & -0.0408 & 1 & \\
\hline TANG & -0.0795 & -0.1017 & -0.0559 & 0.0022 & 0.0306 & 0.0394 & 1 \\
\hline
\end{tabular}

\subsection{Diagnostic Tests}

Diagnostic tests were performed to test for the regression assumptions. The Breusch-Pagan/Cook-Weisberg Test was applied to test the error term in the examined models. The results show that dividend model (chi2 $(1)=2727.07 \&$ Prob > chi2 $=0.0000)$ and capital structure model $($ chi2 $(1)=130.94 \&$ Prob $>$ chi2 $=0.0000)$ have heteroskedasticity problem. Also, the Wooldridge test is used to detect the presence of autocorrelation in the examined models. The results reveal that only capital structure suffer from autocorrelation problem $(\mathrm{F}(1,406)=$ $279.336 \&$ Prob $>F=0.0000)$ and no first-order autocorrelation in the dividend model $(F(1,406)=2.513 \&$ Prob $>$ $\mathrm{F}=0.1137)$. Robust standard error is needed to solve the problem of heteroskedasticity and autocorrelation.

For endogeneity presence in the examined models, the Durbin-Wu- Hausman was performed. The results confirmed that leverage is endogenous variable in the model of dividend (Durbin (score) chi2 $(1)=284.218(\mathrm{p}=0.0000) \&$ Wu-Hausman F $(1,2022)=328.248(\mathrm{p}=0.0000))$. Similarly, dividend is found to be endogenous in the capital structure model (Durbin (score) chi2 $(1)=68.5596(\mathrm{p}=0.0000) \&$ Wu-Hausman $\mathrm{F}(1,2022)=70.4966(\mathrm{p}=$ $0.0000)$ ).

In order to test the identification of the models and validity of instruments, using Stat 15 the rank condition is checked. The results show that both equations are identified, results in an identified system. In addition, Sargan-Hansen test is performed for checking the over-identifying restrictions. The results reveals that instruments are valid for dividend model (Sargan (score) chi2 $(1)=.018719(\mathrm{p}=0.8912) \&$ Basmann chi2 $(1)=.018599(\mathrm{p}=$ $0.8915)$ ) and capital structure model (Sargan (score) chi2 $(1)=7.80338(\mathrm{p}=0.474) \&$ Basmann chi2 $(1)=7.78337$ $(\mathrm{p}=0.557))$.

\subsection{Empirical Findings}

Table 5 shows the results of OLS, 2SLS, and 3SLS for both dividend and capital structure equations. The results show a significant difference across equqsions before and after accounting for endogeneity effect. Generally, for both models capital structure (LEV) and dividends (DIV) have been found to be significant, which proves the simultaneous relationship. Furthermore, the results reported a significant negative relationship between capital structure (LEV) and dividends (DIV) before accounting for endogeneity and a significant positive relationship after accounting for endogeneity effects. This positive relation implies that firms tend to depend on debt to finance their activities rather than using internal finance by reducing dividends.

Table 5. Results of regression analysis

\begin{tabular}{lllllll}
\hline \multirow{2}{*}{ variables } & Dividend & \multicolumn{5}{l}{ Capital Structure } \\
\cline { 2 - 7 } & OLS & 2SLS & 3SLS & OLS & 2SLS & 3SLS \\
\hline \multirow{2}{*}{ DIV } & - & - & - & $-0.0955^{* * * *}$ & $0.0885^{* * * *}$ & $0.0881^{* * *}$ \\
& & & & $(0.000)$ & $(0.000)$ & $(0.001)$ \\
\hline \multirow{2}{*}{ LEV } & $-0.530^{* * *}$ & $4.8256^{* * * *}$ & $4.8289^{* * *}$ & & - & - \\
& $(0.000)$ & $(0.000)$ & $(0.000)$ & - & - & \\
\hline
\end{tabular}




\begin{tabular}{|c|c|c|c|c|c|c|}
\hline $\mathrm{CON}$ & $\begin{array}{l}0.0162 \\
(0.833)\end{array}$ & $\begin{array}{l}0.5930 * * * \\
(0.004)\end{array}$ & $\begin{array}{l}0.5789 * * * \\
(0.005)\end{array}$ & $\begin{array}{l}-0.0925 * * * \\
(0.003)\end{array}$ & $\begin{array}{l}-0.1096^{* * *} \\
(0.001)\end{array}$ & $\begin{array}{l}-0.1095^{* * *} \\
(0.001)\end{array}$ \\
\hline FAMILY & $\begin{array}{l}0.0119 \\
(0.792)\end{array}$ & $\begin{array}{l}0.3043^{* * * *} \\
(0.010)\end{array}$ & $\begin{array}{l}0.3045^{* * *} \\
(0.010)\end{array}$ & $\begin{array}{l}-0.0564 * * * \\
(0.002)\end{array}$ & $\begin{array}{l}-0.0591 * * * \\
(0.002)\end{array}$ & $\begin{array}{l}-0.0591 * * * \\
(0.003)\end{array}$ \\
\hline GOV & $\begin{array}{l}0.3441 * * * \\
(0.000)\end{array}$ & $\begin{array}{l}0.6661 * * * \\
(0.000)\end{array}$ & $\begin{array}{l}0.6713^{* * *} \\
(0.000)\end{array}$ & $\begin{array}{l}-0.0297 \\
(0.280)\end{array}$ & $\begin{array}{l}-0.0985 * * * \\
(0.003)\end{array}$ & $\begin{array}{l}-0.0979 * * * \\
(0.002)\end{array}$ \\
\hline FOREIGN & $\begin{array}{l}0.0614 \\
(0.315)\end{array}$ & $\begin{array}{l}1.0052 * * * \\
(0.000)\end{array}$ & $\begin{array}{l}1.0160 * * * \\
(0.000)\end{array}$ & $\begin{array}{l}-0.1574 * * * \\
(0.000)\end{array}$ & $\begin{array}{l}-0.1885^{* * *} \\
(0.000)\end{array}$ & $\begin{array}{l}-0.1884 * * * \\
(0.000)\end{array}$ \\
\hline TQ & $\begin{array}{l}0.0142 \\
(0.295)\end{array}$ & $\begin{array}{l}0.0684 * * \\
(0.045)\end{array}$ & $\begin{array}{l}0.0691 * * \\
(0.043)\end{array}$ & $\begin{array}{l}-0.0005 \\
(0.914)\end{array}$ & $\begin{array}{l}-0.0130 * * \\
(0.033)\end{array}$ & $\begin{array}{l}-0.013 * * \\
(0.033)\end{array}$ \\
\hline ROA & $\begin{array}{l}1.3052^{* * *} \\
(0.000)\end{array}$ & $\begin{array}{l}5.9794 * * * \\
(0.000)\end{array}$ & $\begin{array}{l}6.0165^{* * *} \\
(0.000)\end{array}$ & $\begin{array}{l}-0.9632 * * * \\
(0.000)\end{array}$ & $\begin{array}{l}-0.9927 * * * \\
(0.000)\end{array}$ & $\begin{array}{l}-0.9936^{* * * *} \\
(0.000)\end{array}$ \\
\hline BETA & $\begin{array}{l}-0.0456^{* *} \\
(0.020)\end{array}$ & $\begin{array}{l}-0.1401 * * * \\
(0.005)\end{array}$ & $\begin{array}{l}-0.1421 * * * \\
(0.004)\end{array}$ & $\begin{array}{l}0.0081 \\
(0.300)\end{array}$ & $\begin{array}{l}0.0239 * * * \\
(0.008)\end{array}$ & $\begin{array}{l}0.0238^{* * *} \\
(0.008)\end{array}$ \\
\hline STDV & $\begin{array}{l}-1.224 * * * \\
(0.000)\end{array}$ & $\begin{array}{l}2.1375^{* *} \\
(0.019)\end{array}$ & $\begin{array}{l}2.0684 * * \\
(0.023)\end{array}$ & $\begin{array}{l}-0.5705^{* * *} \\
(0.000)\end{array}$ & $\begin{array}{l}-0.5262 * * * \\
(0.000)\end{array}$ & $\begin{array}{l}-0.5268^{* * * *} \\
(0.000)\end{array}$ \\
\hline SALEGRTH & $\begin{array}{l}-0.0188 * \\
(0.096)\end{array}$ & $\begin{array}{l}-0.0812^{* * * *} \\
(0.005)\end{array}$ & $\begin{array}{l}-0.0067 \\
(0.555)\end{array}$ & - & - & - \\
\hline FCF & $\begin{array}{l}-3.790 * * * \\
(0.000)\end{array}$ & $\begin{array}{l}1.9075^{* * * *} \\
(0.002)\end{array}$ & $\begin{array}{l}2.1213^{* * *} \\
(0.000)\end{array}$ & - & - & - \\
\hline COVERAG & - & - & - & $\begin{array}{l}0.0465^{* * * *} \\
(0.000)\end{array}$ & $\begin{array}{l}0.0181 * * * \\
(0.003)\end{array}$ & $\begin{array}{l}0.0182 * * * \\
(0.002)\end{array}$ \\
\hline TANG & - & - & - & $\begin{array}{l}0.0191 * * \\
(0.042)\end{array}$ & $\begin{array}{l}0.0151 \\
(0.459)\end{array}$ & $\begin{array}{l}0.0126^{* *} \\
(0.038)\end{array}$ \\
\hline No of obs & 2035 & 2035 & 2035 & 2035 & 2035 & 2035 \\
\hline RMSE & 0.4808 & 1.1757 & 1.1758 & 0.1935 & 0.2136 & 0.2135 \\
\hline Prob > chi2 & 0.000 & 0.000 & 0.000 & 0.000 & 0.000 & 0.000 \\
\hline
\end{tabular}

$* * * \frac{1}{1 \%}$ significance level, $* * 5 \%$ significance level, ${ }^{*} 10 \%$ significance level

The results are consistent with the agency theory predictions that firms, in order to alleviate agency costs, use dividends to reduce excess cash and use debt to increase the dependence on the capital market (Easterbrook, 1984; Jensen, 1986). Yusof et al. (2016) suggested that dividend-induced governance reduces the internal funds available for investment and increase the need for external finance. Adu-Boanyah et al. (2013) suggested that the use of debt reduce the agency cost and improve the firm's profitability, both of which are associated with high dividends.

The results are also consistent with the pecking order theory. Myers (1984) argued that due to the sticky feature of dividends, debt is preferred over equity when firms experience an internal financial deficit. Therefore, high dividend payout increases the probability of internal deficit and, as a consequence more debt is used. Similarly, several studies have reported a positive relationship between dividends and capital structure (Belden et al., 2005; Dutta, 1999; Aggarwal \& Kyaw, 2010; Kim et al., 2007).

The ownership structure is represented in the models by four variables, namely, substantial shareholders as a proxy of the overall ownership concentration (CON), family ownership (FAMILY), government ownership (GOV) and foreign ownership (FOREIGN). The results changed markedly in sign, magnitude and significance when moving from OLS estimator to 2SLS and 3SLS estimators. As for dividend equation, only government ownership (GOV) show significant effect based on OLS estimator. However, after taking into account the endogeneity effect using 
2SLS and 3SLS, all ownership variables (CON, FAMILY, GOV, and FOREIGN) have found to be positively significant. The results are consistent with the monitoring hypothesis, which suggests that controlling shareholders use dividends to apply a strict financial discipline against managerial opportunism (Harada \& Nguyen, 2011). Active monitoring by controlling shareholders minimize the extravagance of corporate resources. Hence the excess cash is paid out as dividends (Shleifer \& Vishny, 1986). Furthermore, the results are inconsistent with the expropriation hypothesis, as the results suggest that there is no attempt by controlling shareholders in Malaysia to extract private benefits at the minority shareholders' expenses or expropriate their wealth. The positive relationship between substantial, family, government, and foreign shareholders with dividends also indicates the presence of strong investor protection in Malaysia.

On the other hand, ownership variables (CON, FAMILY, GOV, and FOREIGN) have a significant negative coefficient in the capital structure model based on both 2SLS and 3SLS. The results indicate that controlling shareholders (substantial, family, government, and foreign shareholders) tend to use less debt. This negative effect supports the substitution hypothesis of agency theory, where the active monitoring of shareholders mitigate the need for debt as a means to monitor mangers (Short et al., 2002). Furthermore, the substantial shareholder who owns an undiversified large portion of the firm may be more cautious regarding the risk associated with debt. Obviously, large shareholders are less affected by control-motivation in Malaysia. As shown in Table 2 the mean of ownership concentration $(\mathrm{CON})$ is $56.8 \%$ which indicate absolute control of large shareholders on the firms. The direct representation of family shareholders in the board with absolute control on the firms' shareholdings rises the managers' entrenchment who are more concern about the risk associated with debt. Similarly, Chen and Strange (2005) suggested that government ownership increases the managers' entrenchment. Another explanation may be that the government and foreign shareholders have a high ability to raise equity financing. Furthermore, unlike domestic investors, foreign investors are exposed to additional risks associated with the instability in macroeconomic variables such as exchange rates and interest rates. Such risks make foreign investors more concern regarding the risks associated with debt. The current results are consistent with the results found by Su (2010) Chen and Strange (2005), and $\mathrm{Li}$ et al. (2009).

With respect to firms' characteristics, results showed that growth opportunities (TQ) and profitability (ROA) negatively affect the capital structure and positively affect dividend payout. The results support the pecking order prediction, firms with high profits have less leverage and higher dividend payout (Fama \& French, 2002). Although pecking order theory predicts a negative relationship between dividend and investment opportunity, Myers' (1984) argued that due to the sticky of dividends policy at the short term, firms meet the growth required funds by either using the cash balance, marketable securities or largely by debt. For corporate risk variables, firms' market risks (BETA) is found to be significant and negatively related to dividends. This result also supports pecking order theory, Rozeff (1982) argued that a firm's risk increases the transaction costs associated with new issuance hence firms with high risk reduce dividend payments to lower the need for external finance. But (BETA) is found to be negative on capital structure. However, based on the assets substitution hypothesis, firms with a high variance in market value are more likely to use higher debt to shift part of firms' risk to bondholders (Green \& Talmor, 1986). Also, corporate risk as measured by the standard deviation of earnings (STDV) has a significant negative effect on the capital structure, which supports the pecking order predictions.

The positive effect of free cash flow (FCF) on dividends supports the agency theory predictions where shareholders use dividends to reduce cash under managers' discretions. In addition, sales growth (SALEGRTH) is found to be negatively related to dividend. In the other hand, coverage ratio (COVERAG) and tangibility (TANG) are found to be positively related to capital structure. The result reinforces the trade-off hypothesis with the assumption that tangible assets serve as a collateral for debt financing and increase the firms' borrowing capacity at a lower cost, fixed assets are the creditors' last resort when firms go bankrupt . which is in accordance with trade-off predictions (Saleh et al. 2018b).

\section{Conclusion}

Unlike previous studies, this study simultaneously examined the effect of corporate ownership variables on capital structure and dividend policy. The investigation is conducted for a sample of listed firms in Malaysia between 2012 and 2016. The results from OLS estimator showed a significant difference in sign, magnitude and significance compared to 2SLS and 3SLS estimators indicating the effect of endogeneity bias. The results of simultaneous regression models using 2SLS and 3SLS confirmed that dividends and capital structure are simultaneously determined, where they are found to affect each other positively. The positive bi-directional relationship between capital structure and dividends is consistent with the predictions of both agency and pecking order theory. The 
dividend-induced governance reduces managers' discretions on free cash flow and keeps the firm under capital monitoring due to persistent needs for external finance. Although pecking order suggests the preference of internal finance over external, Myers (1984) asserted that the reluctance of managers to reduce dividends at short trim push firms with high dividends to use more debt financing.

The study provides evidence on the influence of four ownership identities on the firms' dividend policy and capital structure. The study focused on the effect of four ownership identities namely ownership concentration (substantial), government ownership, family ownership, and foreign ownership. All ownership identities were found to be significant. The positive effect of substantial ownership, government ownership, and foreign ownership on dividends reflects the protection of minority shareholders and supports the monitoring hypothesis that suggests large shareholders monitor management through dividends (Shleifer \& Vishny, 1986).

As for capital structure, similar to the dividend model, all ownership identities (substantial, government, and foreign ownership) were found to be significant and negatively related to capital structure. Clearly, capital structure is not a good governance mechanism for Malaysian firms. The plausible explanation from the agency theory perspective is that ownership concentration offsets the governance role of debt to alleviate agency costs. In addition, controlling shareholders in Malaysia possess absolute control on the firms with a mean concentration of $65.8 \%$. Thus, they concern about the risk of financial distress more than the risk of losing control. However, given the results, a question may be raised as to how firms could keep low debt levels when they distribute most of their internally generated funds in the form of dividends. The possible justification lies in pecking order theory as offered by Myers (1984) and Fama and French (2002) who argued that the consideration of both information asymmetry costs and financial distress costs motivates firms to issue equity to build up financial slack in anticipation of future investment.

The findings of the study provide clear insight to managers regarding the preferences of shareholders toward capital structure and dividend policy and how these choices are affected by the expected conflicts between minority and majority shareholders. Shareholders in Malaysia are shown to prefer high and stable dividend payout. Overall, shareholders tend to use dividends as a monitoring tool but not capital structure. At a high threat of expropriation, high dividends are required to build reputation. Shareholders may tend to channel funds into investment opportunities rather than payout dividends. Such clear vision enhances the managers' performance and enables them to reduce the agency conflicts and information asymmetry. Furthermore, it provides them, early on, with expectations regarding specific changes and the appropriate approach to satisfy the current and expected investors and hence maximize the firm value.

\section{References}

Abdulkadir, R. I., Abdullah, N. A. H., \& Wong, W. C. (2016). Dividend payment behaviour and its determinants: The Nigerian evidence. African Development Review, 28(1), 53-63. https://doi.org/10.1111/1467-8268.12166

Adu-Boanyah, E., Ayentimi, D. T., \& Osei-Yaw, F. (2013). Determinants of dividend payout policy of some selected manufacturing firms listed on the Ghana Stock Exchange. Research Journal of Finance and Accounting, 4(5), 49-60.

Aggarwal, R., \& Kyaw, N. A. (2010). Capital structure, dividend policy, and multinationality: Theory versus empirical evidence. International Review of Financial Analysis, 19(2), 140-150. https://doi.org/10.1016/j.irfa.2010.01.001

Al-Jaifi, H. A. (2017). Ownership concentration, earnings management and stock market liquidity: evidence from Malaysia. Corporate Governance: The International Journal of Business in Society, 17(3), 490-510. https://doi.org/10.1108/CG-06-2016-0139

Al-Malkawi, H.-A. N. (2017). Ownership Structure, Firm-Specific Factors and Payout Policy: Evidence from the GCC Region. Corporate Ownership \& Control, 15(1-2), 476-486. https://doi.org/10.22495/cocv15i1c2p16

Al-Najjar, B., \& Kilincarslan, E. (2016). The effect of ownership structure on dividend policy: Evidence from Turkey. Corporate Governance: The International Journal of Business in Society, 16(1), 135-161. https://doi.org/10.1108/CG-09-2015-0129

Anderson, R. C., \& Reeb, D. M. (2003). Founding-Family ownership, corporate diversification, and firm leverage. Journal of Law and Economics, 46(2), 653-684. https://doi.org/10.1086/377115

Baba, N. (2009). Increased presence of foreign investors and dividend policy of Japanese firms. Pacific-Basin Finance Journal, 17(2), 163-174. https://doi.org/10.1016/j.pacfin.2008.04.001 
Bandyopadhyay, A., \& Barua, N. (2016). Factors Determining Capital Structure and Corporate Performance in India: Studying the Business Cycle Effects. The Quarterly Review of Economics and Finance, 61, 160-172. https://doi.org/10.1016/j.qref.2016.01.004

Baskin, J. (1989). An empirical investigation of the pecking order hypothesis. Financial Management, 18(1), 26-35. https://doi.org/10.2307/3665695

Belden, S., Fister, T., \& Knapp, B. (2005). Dividends and directors: do outsiders reduce agency costs?. Business and Society Review, 110(2), 171-180. https://doi.org/10.1111/j.0045-3609.2005.00009.x

Benjamin, J. S., Mat Zain, M., \& Abdul Wahab, E. A. (2016). Political connections, institutional investors and dividend payouts in Malaysia. Pacific Accounting Review, 28(2), 153-179. https://doi.org/10.1108/PAR-06-2015-0023

Ben-Nasr, H. (2015). Government ownership and dividend policy: Evidence from newly privatised firms. Journal of Business Finance \& Accounting, 42(5-6), 665-704. https://doi.org/10.1111/jbfa.12115

Brailsford, T. J., Oliver, B. R., \& Pua, S. L. (2002). On the relation between ownership structure and capital structure. Accounting \& Finance, 42(1), 1-26. https://doi.org/10.1111/1467-629X.00001

Cameron, A. C., \& Trivedi, P. K. (2005). Microeconometrics: methods and applications. Cambridge University Press. https://doi.org/10.1017/CBO9780511811241

Céspedes, J., González, M., \& Molina, C. A. (2010). Ownership and capital structure in Latin America. Journal of Business Research, 63(3), 248-254. https://doi.org/10.1016/j.jbusres.2009.03.010

Chen, J., \& Strange, R. (2005). The determinants of capital structure: Evidence from Chinese listed companies. Economic Change and Restructuring, 38(1), 11-35. https://doi.org/10.1007/s10644-005-4521-7

Chen, J., Jiang, C., \& Lin, Y. (2014). What determine firms' capital structure in China?. Managerial Finance, 40(10), 1024-1039. https://doi.org/10.1108/MF-06-2013-0163

Croci, E., Doukas, J. A., \& Gonenc, H. (2011). Family control and financing decisions. European Financial Management, 17(5), 860-897. https://doi.org/10.1111/j.1468-036X.2011.00631.x

Dewenter, K. L., \& Malatesta, P. H. (2001). State-owned and privately owned firms: An empirical analysis of profitability, leverage, and labor intensity. The American Economic Review, 91(1), 320-334. https://doi.org/10.1257/aer.91.1.320

Djebali, R. (2015). On the impact of family versus institutional blockholders on dividend policy. Journal of Applied Business Research (JABR), 31(4), 1329-1342. https://doi.org/10.19030/jabr.v31i4.9320

Douma, S., George, R., \& Kabir, R. (2006). Foreign and domestic ownership, business groups, and firm performance: evidence from a large emerging market. Strategic Management Journal, 27(7), 637-657. https://doi.org/10.1002/smj.535

Dutta, A. S. (1999). Managerial ownership, dividend and debt policy in the US banking industry. Managerial Finance, 25(6), 57-68. https://doi.org/10.1108/03074359910766019

Easterbrook, F. H. (1984). Two agency-cost explanations of dividends. The American Economic Review, 47(4), 650-659.

Eng, L. L., \& Mak, Y. T. (2003). Corporate governance and voluntary disclosure. Journal of Accounting and Public Policy, 22(4), 325-345. https://doi.org/10.1016/S0278-4254(03)00037-1

Eriotis, N., Vasiliou, D., \& Ventoura-Neokosmidi, Z. (2007). How firm characteristics affect capital structure: an empirical study. Managerial Finance, 33(5), 321-331. https://doi.org/10.1108/03074350710739605

Faccio, M., Lang, L. H., \& Young, L. (2001). Dividends and expropriation. American Economic Review, 19(1), 54-78. https://doi.org/10.1257/aer.91.1.54

Faccio, M., Marchica, M., \& Mura, R. (2011). Large shareholder diversification and corporate risk-taking. The Review of Financial Studies, 24(11), 3601-3641. https://doi.org/10.1093/rfs/hhr065

Fama, E. F., \& French, K. R. (2002). Testing trade-off and pecking order predictions about dividends and debt. Review of Financial Studies, 15(1), 1-33. https://doi.org/10.1093/rfs/15.1.1 
Farooq, O. (2015). Effect of ownership concentration on capital structure: evidence from the MENA region. International Journal of Islamic and Middle Eastern Finance and Management, 8(1), 99-113. https://doi.org/10.1108/IMEFM-10-2013-0115

Friend, I., \& Lang, L. H. (1988). An empirical test of the impact of managerial self-interest on corporate capital structure. Journal of Finance, 43(2), 271-281. https://doi.org/10.1111/j.1540-6261.1988.tb03938.x

Ghasemi, M., Razak, N., \& Muhamad, J. (2018). Dividends, leverage and endogeneity: A simultaneous equations study on Malaysia. Australasian Accounting, Business and Finance Journal, 12(1), 47-64. https://doi.org/10.14453/aabfj.v12i1.4

Green, R. C., \& Talmor, E. (1986). Asset substitution and the agencycosts of debt financing. Journal of Banking \& Finance, 10(3), 391-399. https://doi.org/10.1016/S0378-4266(86)80028-0

Gurunlu, M., \& Gursoy, G. (2010). The Influence of Foreign Ownership on Capital Structure of Non-Financial Firms: Evidence from Istanbul Stock Exchange. IUP Journal of Corporate Governance, 9(4), 21-29.

Haniffa, R., \& Hudaib, M. (2006). Corporate governance structure and performance of Malaysian listed companies. Journal of Business Finance \& Accounting, 33(7-8), 1034-1062. https://doi.org/10.1111/j.1468-5957.2006.00594.x

Harada, K., \& Nguyen, P. (2011). Ownership concentration and dividend policy in Japan. Managerial Finance, 37(4), 362-379. https://doi.org/10.1108/03074351111115313

Hardiyanto, A. T., Achsani, N. A., Sembel, R., \& Maulana, N. A. (2015). Ownership and determinants capital structure of public listed companies in Indonesia: A panel data analysis. International Research Journal of Business Studies, 6(1), 29-43. https://doi.org/10.21632/irjbs.6.1.29-43

Jabbouri, I. (2016). Determinants of corporate dividend policy in emerging markets: Evidence from MENA stock markets. Research in International Business and Finance, 37, 283-298. https://doi.org/10.1016/j.ribaf.2016.01.018

Jensen, G. R., Solberg, D. P., \& Zorn, T. S. (1992). Simultaneous determination of insider ownership, debt, and dividend policies. Journal of Financial and Quantitative Analysis, 27(2), 247-263. https://doi.org/10.2307/2331370

Jensen, M. C. (1986). Agency cost of free cash flow, corporate finance, and takeovers. The American Economic Review, 76(2), 323-329.

Jensen, M. C., \& Meckling, W. H. (1976). Theory of the firm: Managerial behavior, agency costs and ownership structure. Journal of Financial Economics, 3(4), 305-360. https://doi.org/10.1016/0304-405X(76)90026-X

Jeon, J. Q., Lee, C., \& Moffett, C. M. (2011). Effects of foreign ownership on payout policy: Evidence from the Korean market. Journal of Financial Markets, 14(2), 344-375. https://doi.org/10.1016/j.finmar.2010.08.001

Khan, A. S., \& Adom, A. Y. (2015). A test of the pecking order theory of capital structure in corporate finance. Accounting \& Taxation, 7(2), 43-49.

Kim Ph, Y. H., Rhim, J. C., \& Friesner, D. L. (2007). Interrelationships among capital structure, dividends, and ownership: evidence from South Korea. Multinational Business Review, 15(3), 25-42. https://doi.org/10.1108/1525383X200700011

Köksal, B., \& Orman, C. (2015). Determinants of capital structure: evidence from a major developing economy. Small Business Economics, 44(2), 255-282. https://doi.org/10.1007/s11187-014-9597-x

Kuwari, D. (2009). Determinants of the dividend policy in emerging stock exchanges: The case of GCC countries. Global Economy \& Finance Journal, 2(2), 38-63.

La Porta, R., Lopez-de-Silanes, F., Shleifer, A., \& Vishny, R. W. (2000a). Agency problems and dividend policies around the world. The Journal of Finance, 55(1), 1-33. https://doi.org/10.1111/0022-1082.00199

La Porta, R., Lopez-de-Silanes, F., Shleifer, A., \& Vishny, R. W. (2000b). Investor protection and corporate governance. Journal of Financial Economics, 58(1), 3-27. https://doi.org/10.1016/S0304-405X(00)00065-9

Lam, K. C., Sami, H., \& Zhou, H. (2012). The role of cross-listing, foreign ownership and state ownership in dividend policy in an emerging market. China Journal of Accounting Research, 5(3), 199-216. https://doi.org/10.1016/j.cjar.2012.06.001 
Le, T. P. V., \& Tannous, K. (2016). Ownership structure and capital structure: A study of Vietnamese listed firms. Australian Economic Papers, 55(4), 319-344. https://doi.org/10.1111/1467-8454.12089

Lean, H. H., Ting, I. W. K., \& Kweh, Q. L. (2015). Ownership concentration, family ownership and leverage: Evidence from Malaysia. Malaysian Journal of Economic Studies, 52(2), 117-133.

Lee, C.-F., Liang, W.-L., Lin, F.-L., \& Yang, Y. (2016). Applications of simultaneous equations in finance research: methods and empirical results. Review of Quantitative Finance and Accounting, 47(4), 943-971. https://doi.org/10.1007/s11156-015-0526-0

Li, K., Yue, H., \& Zhao, L. (2009). Ownership, institutions, and capital structure: Evidence from China. Journal of Comparative Economics, 37(3), 471-490. https://doi.org/10.1016/j.jce.2009.07.001

Lin, T., Chen, Y.-R., \& Tsai, H.-F. (2017). The relationship among information asymmetry, dividend policy and ownership structure. Finance Research Letters, 20, 1-12. https://doi.org/10.1016/j.frl.2016.06.008

Lin, Y.-H., Chiou, J.-R., \& Chen, Y.-R. (2010). Ownership structure and dividend preference: Evidence from China's privatized state-owned enterprises. Emerging Markets Finance and Trade, 46(1), 56-74. https://doi.org/10.2753/REE1540-496X460106

Manos, R. (2002). Dividend policy and agency theory: evidence on Indian firms. Institute for Development Policy and Management, University of Manchester.

McConaughy, D. L. (2009). The cost of capital for the closely-held, family-controlled firm. USASBE Proceedings, $1-13$.

Mehran, H. (1992). Executive incentive plans, corporate control, and capital structure. Journal of Financial and Quantitative Analysis, 27(4), 539-560. https://doi.org/10.2307/2331139

Mian, R., \& Nagata, K. (2015). Foreign institutional ownership and the valuation effect of investment and payout decisions. Journal of Finance and Economics, 3(5), 97-104.

Mookerjee, R. (1992). An empirical investigation of corporate dividend pay-out behaviour in an emerging market. Applied Financial Economics, 2(4), 243-246. https://doi.org/10.1080/758527107

Mulyani, E., Singh, H., \& Mishra, S. (2016). Dividends, Leverage, and Family Ownership in the Emerging Indonesian Market. Journal of International Financial Markets, Institutions and Money, 43, 16-29. https://doi.org/10.1016/j.intfin.2016.03.004

Myers, S. C. (1977). Determinants of corporate borrowing. Journal of Financial Economics, 5(2), 147-175. https://doi.org/10.1016/0304-405X(77)90015-0

Myers, S. C. (1984). The capital structure puzzle. The Journal of Finance, 39(3), 574-592. https://doi.org/10.1111/j.1540-6261.1984.tb03646.x

Nhung, L. T. P., \& Okuda, H. (2015). Effects of state ownership on companies' capital structure and profitability: Estimation analysis before and after the Lehman shock. Journal of Asian Economics, 38, 64-78. https://doi.org/10.1016/j.asieco.2015.04.001

Pindado, J., Requejo, I., \& Torre, C. (2012). Do family firms use dividend policy as a governance mechanism? Evidence from the Euro zone. Corporate Governance: An International Review, 20(5), 413-431. https://doi.org/10.1111/j.1467-8683.2012.00921.x

Pindado, J., Requejo, I., \& Torre, C. (2015). Does Family Control Shape Corporate Capital Structure? An Empirical Analysis of Eurozone Firms. Journal of Business Finance and Accounting, 42(7-8), 965-1006. https://doi.org/10.1111/jbfa.12124

Pöyry, S., \& Maury, B. (2010). Influential ownership and capital structure. Managerial and Decision Economics, 31(5), 311-324. https://doi.org/10.1002/mde.1477

Rajan, R. G., \& Zingales, L. (1995). What do we know about capital structure? Some evidence from international data. The Journal of Finance, 50(5), 1421-1460. https://doi.org/10.1111/j.1540-6261.1995.tb05184.x

Roberts, M. R., \& Whited, T. M. (2013). Endogeneity in empirical corporate finance. Handbook of the Economics of Finance, 2, 493-572. https://doi.org/10.1016/B978-0-44-453594-8.00007-0 
Rossi, F., Rossi, F., Cebula, R. J., \& Cebula, R. J. (2016). Debt and ownership structure: evidence from Italy. Corporate Governance: The International Journal of Business in Society, 16(5), 883-905. https://doi.org/10.1108/CG-02-2016-0025

Rozeff, M. S. (1982). Growth, beta and agency costs as determinants of dividend payout ratios. Journal of Financial Research, 5(3), 249-259. https://doi.org/10.1111/j.1475-6803.1982.tb00299.x

Saleh, M. S. A. H., Ibrahim, Y., \& Shahar, H. K. (2018a). The Moderating Effect of Growth Opportunity on the Relationship between Corporate Ownership and Dividend Policy. Asian Journal of Multidisciplinary Studies, $6(9), 15-26$.

Saleh, M. S. A. H., Ibrahim, Y., \& Shahar, H. K. (2018b). The Determinant of Capital Structure of Malaysian Firms: Test of Pecking Order and Trade-off Theories under Different Corporate Ownership Identities. IOSR Journal of Economics and Finance, 9(4), 61-70.

Setia-Atmaja, L. (2010). Dividend and debt policies of family controlled firms: the impact of board independence. International Journal of Managerial Finance, 6(2), 128-142. https://doi.org/10.1108/17439131011032059

Shleifer, A., \& Vishny, R. W. (1986). Large shareholders and corporate control. The Journal of Political Economy, 49(3), 461-488. https://doi.org/10.1086/261385

Shleifer, A., \& Vishny, R. W. (1997). A survey of corporate governance. The Journal of Finance, 52(2), 737-783. https://doi.org/10.1111/j.1540-6261.1997.tb04820.x

Short, H., Keasey, K., \& Duxbury, D. (2002). Capital structure, management ownership and large external shareholders: a UK analysis. International Journal of the Economics of Business, 9(3), 375-399. https://doi.org/10.1080/1357151021000010382

$\mathrm{Su}$, L. D. (2010). Ownership structure, corporate diversification and capital structure: Evidence from China's publicly listed firms. Management Decision, 48(2), 314-339. https://doi.org/10.1108/00251741011022644

Suhaila, M. K., Mahmood, W., \& Mansor, W. (2008). Capital structure and firm characteristics: Some evidence from Malaysian companies.

Tam, O. K., \& Tan, M. G. S. (2007). Ownership, governance and firm performance in Malaysia. Corporate Governance: An International Review, 15(2), 208-222. https://doi.org/10.1111/j.1467-8683.2007.00555.x

Vo, D. H., \& Nguyen, V. T. Y. (2014). Managerial ownership, leverage and dividend policies: Empirical evidence from Vietnam's listed firms. International Journal of Economics and Finance, 6(5), 274-284. https://doi.org/10.5539/ijef.v6n5p274

Wooldridge, J. M. (2010). Econometric analysis of cross section and panel data. MIT Press.

Yoshikawa, T., \& Rasheed, A. A. (2010). Family Control and Ownership Monitoring in Family-Controlled Firms in Japan. Journal of Management Studies, 47(2), 274-295. https://doi.org/10.1111/j.1467-6486.2009.00891.x

Yusof, Y., Ismail, S., \& Ali, A. (2016). Determinants of dividend policy of public listed companies in Malaysia. Review of International Business and Strategy, 26(1), 88-99. https://doi.org/10.1108/RIBS-02-2014-0030

\section{Copyrights}

Copyright for this article is retained by the author(s), with first publication rights granted to the journal.

This is an open-access article distributed under the terms and conditions of the Creative Commons Attribution license (http://creativecommons.org/licenses/by/4.0/). 